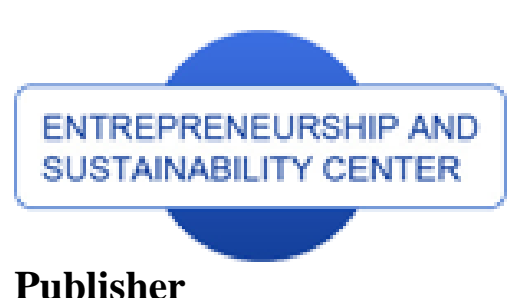

Publisher

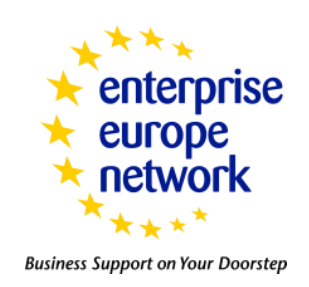

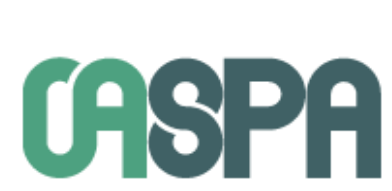

THOMSON REUTERS

Emerging Sources Citation Index WEB OF SCIENCETM

\title{
TECHNOLOGIES FOR SUSTAINABLE CIRCULAR BUSINESS: USING CRUSHING DEVICE FOR USED TIRES
}

\author{
Ina Tetsman', Kristina Baziené2, Gintas Viselga ${ }^{3}$ \\ ${ }^{1,2,3}$ Faculty of Mechanics, Vilnius Gediminas Technical University, Basanavicius st. 28, LT-03224, Lithuania \\ E-mails. ${ }^{1}$ ina.tetsman@vgtu.lt; ${ }^{2}$ kristina.baziene@vgtu.lt; ${ }^{3}$ gintas.viselga@vgtu.lt
}

Received 15 December 2016; accepted 20 March 2017

\begin{abstract}
Technological entrepreneurship plays increasing role in our path towards sustainble economy. Tires, stored in landfills, pose a risk to human health and environment. There may be long and dangerous fires, combustion process produces pollution, extremely dangerous to human health and environment. Therefore, in order to reduce the surplus of tires in landfills, this work investigates the dependence of tyre tread crushed machine output on the usage of the saws with different technical characteristics as well as the dependence of the machine output on the feed rate and the crushed cutting angle. The temperature dependence on the crushed cutting angle and feed is investigated. The particle sizes obtained during tyre tread crushed are also analysed. The study showed that the maximum machine output is $502 \mathrm{~g} / \mathrm{min}$, and as much as $62 \%$ of the resulting particle sizes are up to $0.63 \mathrm{~mm}$, which is the most suitable size for the use as an adsorbent for oil products. It was established that the increase of the crushed cutting angle leads to the increase of the temperature of the circular saw by $26 \%$.
\end{abstract}

Keywords: technological entrepeneurship, tires, crushed, sustainability, production

Reference to this paper should be made as follows: Tetsman, I.; Bazienè, K.; Viselga, G. 2017. Technologies for sustainable circular business: using crushing device for used tires, Entrepreneurship and Sustainability Issues 4(4): 432-440. http://doi.org/10.9770/jesi.2017.4.4(3)

JEL Classifications: L60

Additional disciplines (besides field of economics reflected in JEL classifications): environmental engineering

\section{Introduction}

The goals of the 2030 AGENDA for Sustainable Development of the United Nations is to achieve the environmentally sound management of wastes throughout their life cycle and significantly reduce their release into air water and soil in order to minimize the adverse human health and the environment impacts till 2020 (Baziene et al. 2014; Baziene and Vaiskunaite 2016; Tetsman et al. 2017).

Technological entrepreneurship plays crucial role in the process of moving towards circular economy and is widely discussed (e.g. Bilan et al. 2017; Tvaronavičienè, Černevičiūtẻ 2015; Teletov et al. 2017; Strielkowski et al. 2016; Banaité, Tamošiūnienè 2016; Barberis,et al. 2017; García-Fuentes, de Torre 2017). 
Tires, stored in landfills, pose a risk to human health and environment. Leaching of hazardous substances (heavy metals, carcinogenic organic compounds) into soil or groundwater is possible (Chitsan et al. 2010; Alisauskas et al. 2012). There may be long and dangerous firies, combustion process produces pollution, extremely dangerous to human health and environment. Tires in landfills create favourable conditions for the multiplication of dangerous pathogens. They occupy large areas of land. All these factors only confirm the need to recycle used automotive tires.

Pyrolysis (decomposition at high temperature about $500^{\circ} \mathrm{C}$ ) of raw materials results in rather low quality technical hydrocarbon (due to the high ash, coke and oil content) and combustible gas, which is used in maintaining the operation of the machine, and metal cord. The main drawback to this method is its cyclical nature; it is not possible to carry out continuous production, and the emission levels of toxic pyrolysis products, that are dangerous to environment and human health, are high. The resulting product is of low quality and expensive, this leads to economic inefficiency of the process, but there ways for improvement to make this method efficient.

Dissolution of raw materials in hot bitumen. The recycling by using this method produces the raw material for road building, and modified bitumen is produced. The technology is highly energy-consuming and the product obtained is more expensive than the traditional asphalt concrete mixtures.

Burning of partially crushed tires. This method is widely used in the United States, where the raw material is mixed into the coal used for burning in thermal power plants and for drying cement. The burning of tires in cement plants is quite efficient, as the combustion process takes place at high $\left(1100^{\circ} \mathrm{C}\right)$ temperatures, and the quantity of toxic materials generated is low, and those generated settle in cement and are not released into atmosphere.

Thermo-mechanical method. The thermo-mechanical method is technically perfect rubber regeneration method that allows speeding up the process significantly and making it continuous as well as ensuring the lowering the regenerate production costs due to the maximization of process mechanisation and automation. By applying this method for rubber waste processing, rubber crumbs are continuously mixed with plasticizer and pass through the worm press with an extended housing. The devulcanised product, when leaving the press, is processed with refining rollers to obtain a regenerate (Ayse et al. 2010; Čereška et al. 2016).

Mechanical-pressure destruction method is one of the most widely used rubber waste processing methods. Processed rubber powder is marketed as a secondary raw material. Physical analysis aimed to establish qualitative indicators of rubber particles is carried out periodically to meet environmental challenges and to obtain economic benefits (Uruburu et al. 2013). By applying this method tyre rubber is turned into powder, scrap metal and textile fibres. The protecting steel rings are removed from tyre at the beginning of the process and the tyre is cut into several pieces. Passenger car tires up to $20 \mathrm{~kg}$ are recycled without any preparatory phase (they are neither crushed nor their steel rings are removed). A tyre is placed into a cylindrical press chamber and substantially compressed with the help of a plunger. The major part of the rubber with textile cord is pressed out through the holes at the bottom of the camera. Thus obtained, rubber pieces with textile are further crushed and metal separated by magnetic separators. The textile cord is separated from the crushed rubber. The collected rubber is 
further chipped in the final crushed device. The resulting rubber particles are separated into desired particle sizes by the vibrating sieve.

\section{Use of crushed tyre particles as an adsorbent}

Adsorption is the absorption of a substance from a gas or liquid at the adsorbent surface. Adsorption treatment method is based on the use of the physical properties of some solid materials, having ultramicroscopic structure, so as to isolate individual components from a fluid mixture and keep them on the surface. The adsorption process consists of three successive stages: diffusion of the absorbed material from the flow to the outer surface of the adsorbent (external diffusion), the access of the molecules, having reached the outer surface, to sorption areas inside a porous grain (internal diffusion) and molecular sorption on the inner grain surface (Wu et al. 2009).

Adsorbents are insoluble materials, which, without getting swelled by more than $50 \%$ in excess liquid, retain the liquid in its capillaries and pores on its surface. In order to use the sorbents for the removal of oil spill, they are to be hydrophobic and, at the same time, absorbing oil well. Sorbents are commonly used for the removal of oil product residues or in the places where oil products cannot be reached when using special equipment. Sorbents can also be used for removal of minor oil spillages. When used to for the elimination of oil products, they are, in accordance with the approved local and state rules and requirements, to be removed. All oil products, extracted after sorbent regeneration, are to be properly removed or recycled (Chitsan et al. 2010).

When choosing one or another type of sorbent for the liquidation of oil products, one must take into account certain properties of sorbents and oil products: keeping of oil products, adsorption speed, sorbent customisation. Keeping of oil products. The sorbent may release oil accumulated in its pores, when it is collected from the water surface. Lower viscosity petroleum products are released from pores much easier compared with more viscous ones. Adsorption speed. More viscous oil products adsorb on the adsorbent surface much more effectively compared with the lighter ones. Sorbent customisation. Sorbents may be supplied to oil pollution sources mechanically (using a blower fan) or manually. However, clay and vermiculite, natural inorganic sorbents spread dust and it is difficult to supply them by blowing.

Many natural sorbents are adapted to absorb oil products and are modified. These changes increase the sorbent regeneration capabilities, make them widely used and, at the same time, increase their price. Sorbents used for the removal of oil products are classified according to their use specifications: adsorbents for the adsorption of oil products from the water surface, adsorbents for the adsorption of industrial pollutants, adsorbents for the adsorption of oil products from the ground.

Aisien et al. (2012) had demonstrated the ability of the recycled rubber to adsorb oil and manage simple oil pollution processes due to inner rubber qualities. Laboratory results had shown that tyre powder can be used repeatedly and it is elastic. The tyre powder has a lower adsorption capacity compared with materials that were specially invented to absorb oil. The advantage of tyre powder is that it is possible to use it repeatedly, adsorbing oil after recovery.

\section{Progress of tyre tread crushed experiment}

The tyre with the dimensions of $17.5 \mathrm{R} 25$ was used during the research tests. 29 circular saws NOOK 200x50x1.536 and 5 circular saws NOOK 450x50x2-z56 were applied on the cutting for tyre tread crushed. It is worth to note that the crushed cutting of the patented device was at the angle $\beta$, which may not be reduced, so crushed cutting angle $\beta$ was only to be increased during further testing. Hence the crushing-cutting angle was changed to $5^{\circ}, 6^{\circ}$, 
$7^{\circ}$ and $8^{\circ}$. Before the test the ambient temperature was measured as being $\mathrm{T}=13.6{ }^{\circ} \mathrm{C}$. The relative humidity of the air was also measured and was $r=55 \%$.

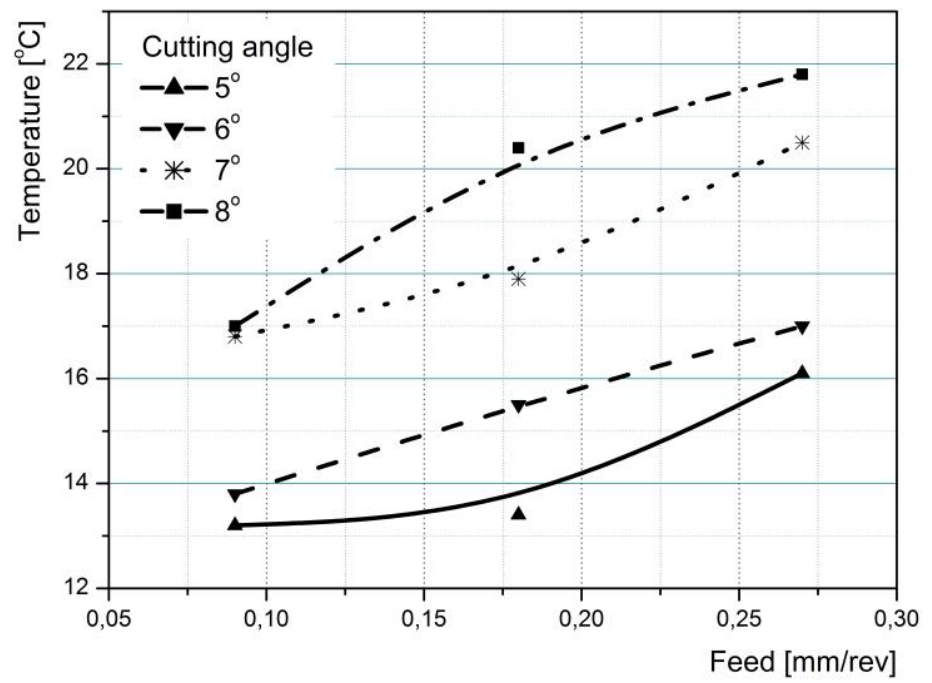

Fig 1. Dependence of temperature from feed and cutting angle of circular saw NOOK 200x50x1.5-36 Source: authors.

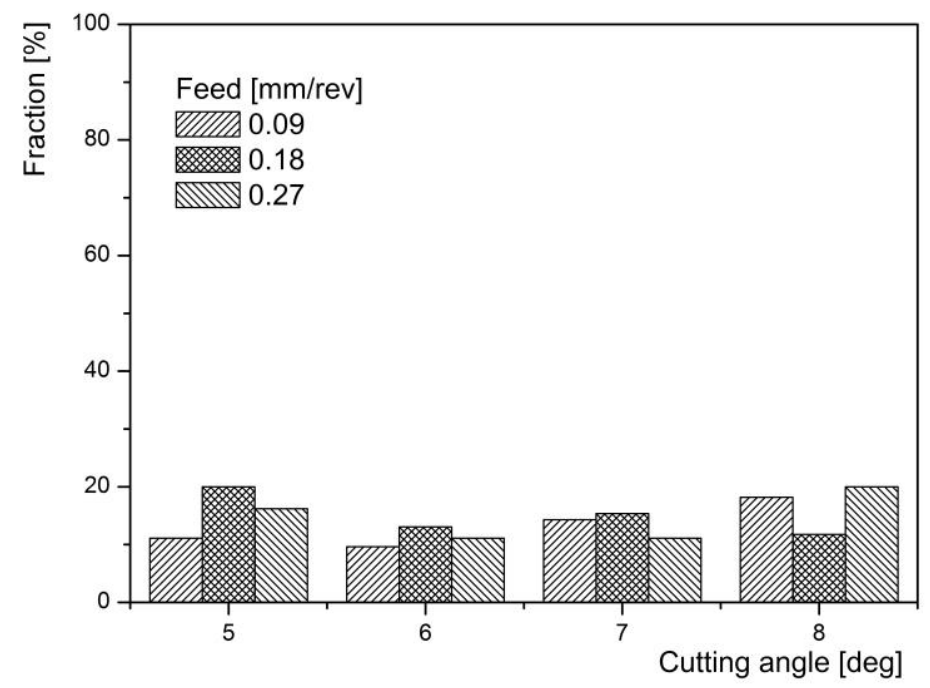

Fig 2. Dependence of fraction $\leq 0.63 \mathrm{~mm}$ from feed and cutting angle of circular saw NOOK 200x50x $1.5-36$ Source: authors. 


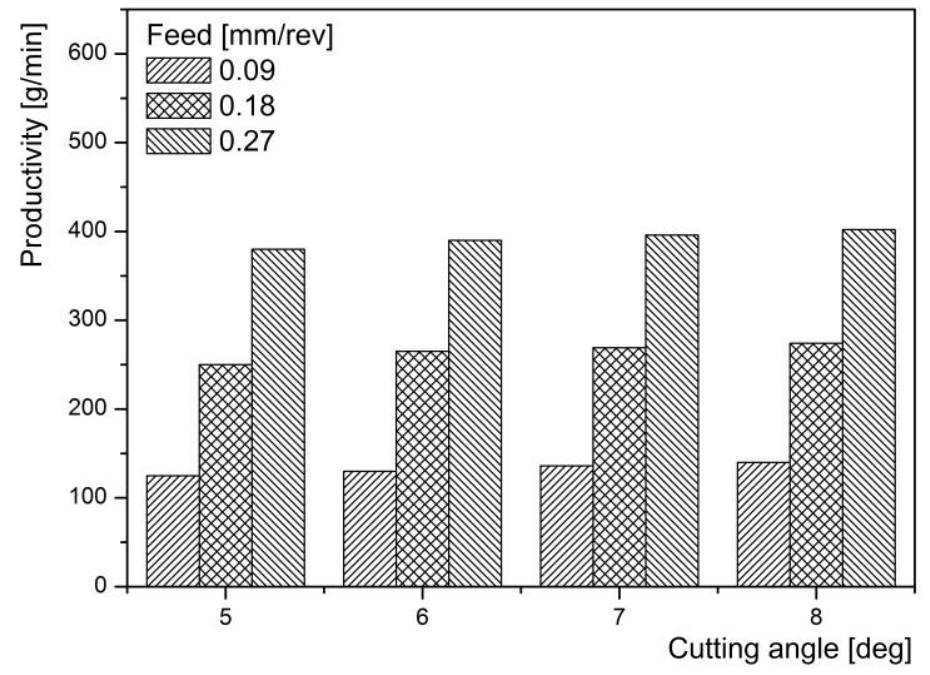

Fig 3. Dependence of production from feed and cutting angle of circular saw NOOK 200x50x1.5-36 Source: authors.

The analysis of the diagram in Fig. 1-3 leads to the conclusion that the tyre tread crushed with the saw NOOK 200x50x1.5-36 tends to overheat. However, it is not recommended to renounce the use of the maximum cutting feed rate, i.e. $0.27 \mathrm{~mm} / \mathrm{rev}$, to reduce the crushed saw average temperatures, as this would reduce the output of the used tyre tread crushed device. However, the angle of the crushed cutting, which has a major impact on the crushed saw temperature increases (Fig. 1), but has not get any impact on the production (Fig. 3). The diagram in Figure 3 shows that the quantities of the smallest particles, which are up to $0.63 \mathrm{~mm}$, are in percentages of between $9.63 \%$ and $20 \%$. It is worth to note that there is no clear trend of the dependence on the crushed cutting angle or on the feed. However, it can be maintained that it would be sufficient to maintain the initial crushed cutting angle and simply increase the feed rate up to the maximum in order to obtain about $20 \%$ of the sizes up to $0.63 \mathrm{~mm}$. This would reduce the heating problem, and the quantity of the smallest particle sizes up to $0.63 \mathrm{~mm}$ obtained would be very similar to that at the maximum crushed cutting angle.

The use of the saw NOOK 450x50x2-z56 during the research test has shown (Fig. 4-6) the maximum device output is achieved at the highest possible tyre tread milling machine feed rate, i.e. at $0.27 \mathrm{~mm} / \mathrm{rev}$. From 380 grams to 402 grams are obtained, depending on the crushed cutting angle, and one can see that the increase of the crushed cutting angle $\beta$ increases the output by $5.47 \%$. However, one has to keep in mind that the temperature of the circular saw NOOK 450x50x2-z56 rises with the increase of the crushed cutting angle $\beta$. Fig. 4 shows that the temperature increases as much as by $25.69 \%$. Therefore it would not be appropriate to increase the device output by increasing the crushed cutting angle $\beta$, as it escalates the circular saw overheating problem. 


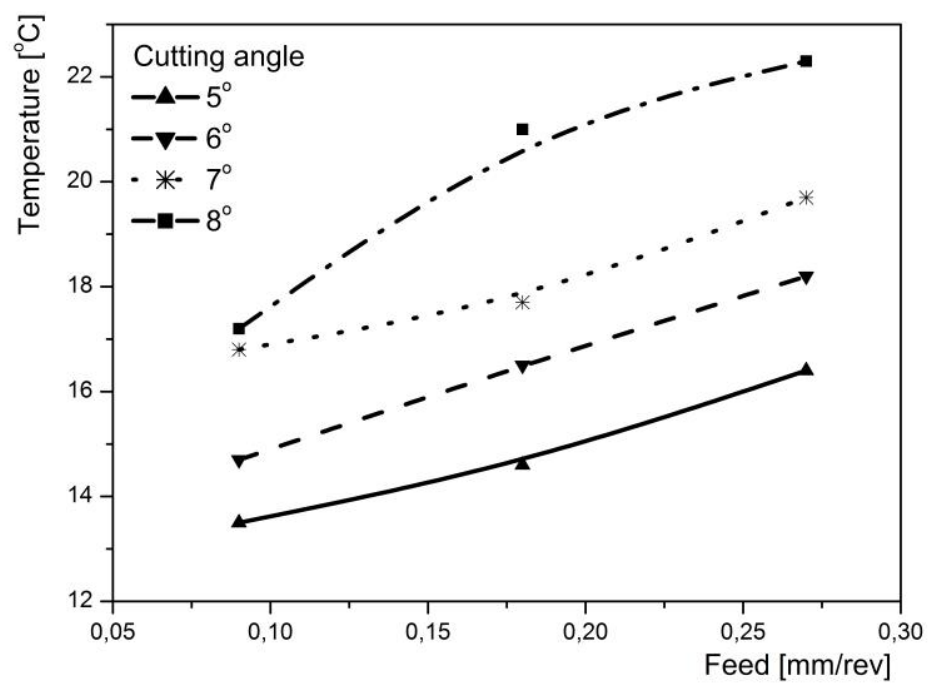

Fig 4. Dependence of temperature from feed and cutting angle of circular saw NOOK 450x50x2-z56 Source: authors.

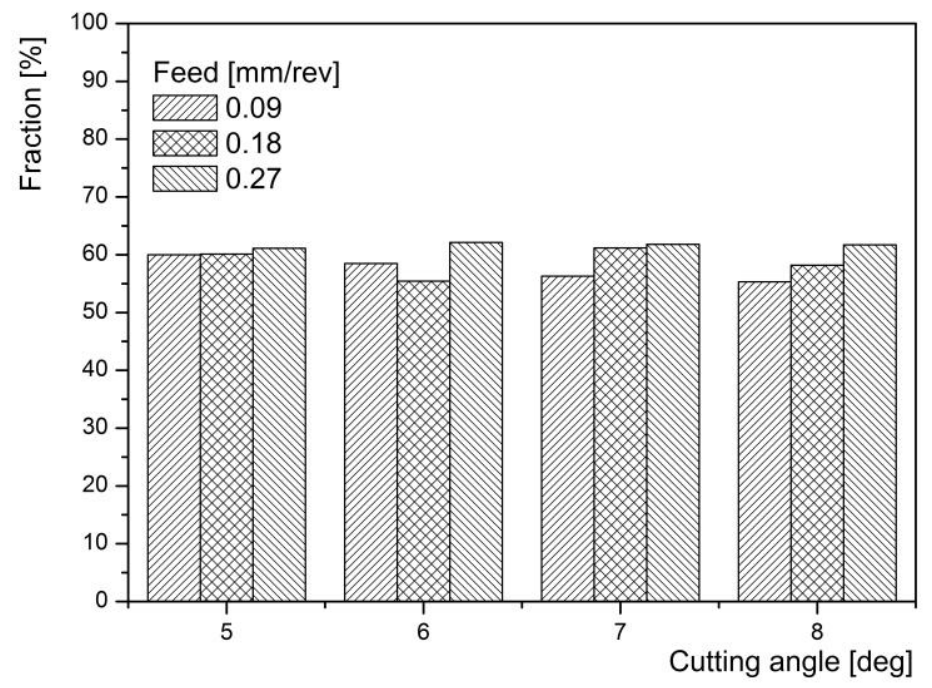

Fig 5. Dependence of fraction (till $0.63 \mathrm{~mm}$ ) from feed and cutting angle of circular saw NOOK 450x50x2-z56 Source: authors.

The diagram in Fig. 5 shows that the crushed of the tyre tread with a saw NOOK 450x50x2-z56 also tends to overheating. However, it is necessary to use the maximum cutting feed rate of $0.27 \mathrm{~mm} / \mathrm{rev}$, because otherwise the used tyre tread crushed device output would be reduced. Therefore, the crushed saw heating reduction potential also remains without changing the crushed cutting angle; but it can only be confirmed by the comparison of the dependence of the crushed particle sizes on the crushed cutting angle $\beta$. 


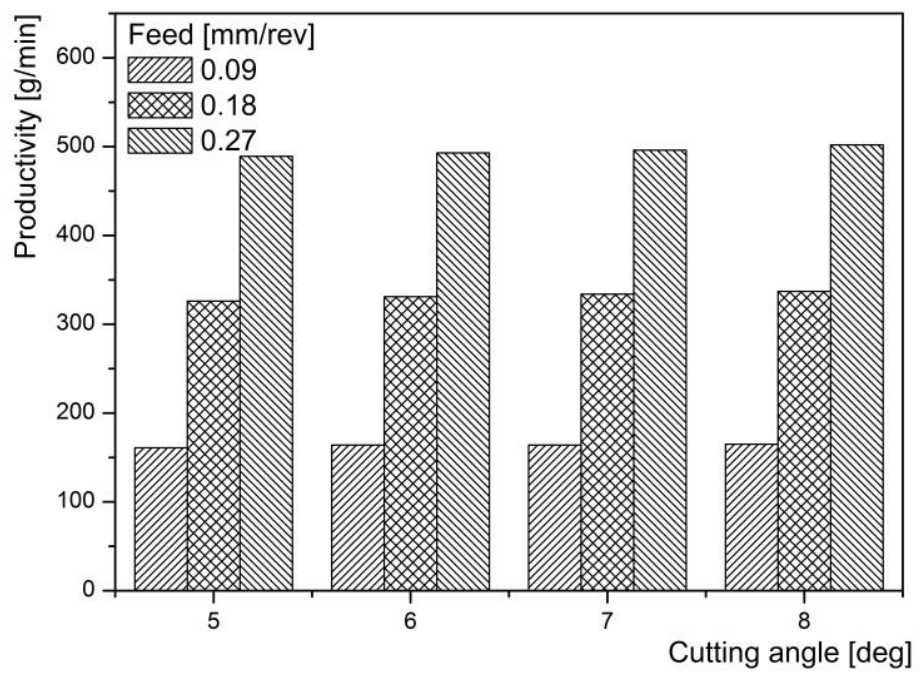

Fig 6. Dependence of production from feed and cutting angle of circular saw NOOK 450x50x2-z56 Source: authors.

The diagram in Fig. 6 shows that the increase of crushed cutting angle $\beta$ had no impact on the increase of the quantity of the crushed particles of the sizes up to $0.63 \mathrm{~mm}$, however the maximum feed rate should be used in order to obtain the smallest particle sizes. The trend observed is that in all the tests when crushed cutting angle is increased and maximum feed rate, which is $0.27 \mathrm{rev} / \mathrm{min}$, approximately $62 \%$ of the particle sizes obtained is up to $0.63 \mathrm{~mm}$. Fig. 6 shows that the maximum tyre tread crushed device output is achieved at the maximum device feed rate, which ranged, depending on the crushed cutting angle $\beta$, from 489 grams to 502 grams per minute, i.e., the output had increased by further $2.59 \%$ with the increase of the crushed cutting angle. However, the increase of the crushed cutting angle led to the increase of the circular saw temperatures, see Fig. 5, by as much as 26 per cent. Therefore, the tests with the first and saw 450x50x2-z56 lead to the conclusion that the maximum feed rate could be used for the improved device output, the increase the crushed cutting angle to increase the device output is a wrong decision.

The comparison of the first (Fig. 3) and second (Fig. 6) tests shows the $40 \%$ increase of the quantity of the particle sizes up to $0.63 \mathrm{~mm}$ during the second test. One can maintain that the saw 450x50x2-z56 should be used for the crushed of used tyre tread to obtain as small particle sizes as possible.

\section{Conclusions}

The study revealed the possibility for the sustainable circular business use of tires as a reuse material using crushing device. Technological solutions can help to minimise the usages of raw material and this requires new additional studies.

The maximum yield of $502 \mathrm{~g} / \mathrm{min}$ is obtained when operating of the saw $450 \times 50 \times 2-\mathrm{z} 56$, the technical characteristics of which are shown in fig 6. 
The test had shown that the heating of the device circular saw is reduced by 26.46 per cent, when the saw $450 \times 50 \times 2-z 56$ is chosen, the crushed cutting angle $\beta$ is not changed and the maximum feed rate of $0.27 \mathrm{~mm} / \mathrm{rev}$ is used.

The sieving of the particles obtained during the tests into four size groups resulted in approximately $62 \%$ of the smallest particle sizes up to $0.63 \mathrm{~mm}$, having the best adsorption properties. When using the saw $450 \times 50 \times 2-\mathrm{z} 56$, under the following conditions: feed rate of $0.27 \mathrm{~mm} / \mathrm{rev}$; crushed cutting angle $\beta$ of $5^{\circ}$.

\section{References}

Aisien, F. A.; Aisien, T. E. 2012. Application of activated recycled rubber from used tyres in oil spill clean up. Turkish Journal of Engineering Environmental Sciences (36), 171 - 177.

Ališauskas, T.; Viselga, G.; Jasinskas A. 2012. Biomasès deginimo tyrimai Vaidotų katilinèje. Mokslas - Lietuvos ateitis. Vilnius: Technika (4) 6: 519-522.

Ayse, E.; Baykal, G.; Saygil1, A. 2010. Influence of different processing techniques on the mechanical properties of used tires in embankment construction. Waste Management. Volume 30(6): 1073-1080

Banaite, D.; Tamošiūnienè, R. 2016. Sustainable development: the circular economy indicators' selection model, Journal of Security and Sustainability Issues 6(2): 315-323. http://dx.doi.org/10.9770/jssi.2016.6.2(10)

Barberis, S.; Roncallo, F.; Traverso, A. 2017. Towards innovative district energy management: a case study with stochastic renewable generators, Entrepreneurship and Sustainability Issues 4(3): 294-309. http://dx.doi.org/10.9770/jesi.2017.4.3S(5)

Baziene, K.; Vaiskunaite, R. 2016. Research of Sustainable Use of Tire Shreds in Landfill. Sustainability. 8(8) 371-378 http://doi.org/10.3390/su8080767

Baziene, K.; Vasarevicius, S.; Ndeapo, N. 2014. Research of landfill drainage layer clogging. In Proceedings of the 9th International Conference "Environmental Engineering”, Vilnius, Lithuania, 22-23 May 2014.

Bilan, Y.; Strielkowski, W.; Karbach, R.; Mentel, G. 2017. Secure development of country and competitiveness issues: case of Germany's energy security, Journal of Security and Sustainability Issues 6(3): 329-342. http://dx.doi.org/10.9770/jssi.2017.6.3(1)

Chitsan, L.; Hong, Y.; Allen, H. H. 2010. Using a composite material containing waste tire powder and polypropylene. Waste Management 30(2): 263-7. http://doi.org/10.1016/j.wasman.2009.03.001

Čereška A.; Zavadskas E. K.; Cavallaro F.; Podvezko V.; Tetsman I.; Grinbergienè I. 2016. Sustainable assessment of aerosol pollution decrease applying multiple attribute decision-making methods. Sustainability 8(7): 1-12.

García-Fuentes, M. A.; de Torre, C. 2017. Towards smarter and more sustainable regenerative cities: the REMOURBAN model, Entrepreneurship and Sustainability Issues 4(3): 328-338. http://dx.doi.org/10.9770/jesi.2017.4.3S(8)

Pomerleau D. G., Gibbs K.W. 2010. Methods of Utilizing Recycled Rubber. United States Patent, Patent no. US7850855 B2, B01D15/04

Strielkowski, W.; Lisin, E.; Tvaronavičienè, M. 2016. Towards energy security: sustainable development of electrical energy storage, Journal of Security and Sustainability Issues 6(2): 235-244. http://dx.doi.org/10.9770/jssi.2016.6.2(4)

Teletov, A.; Nagornyi, Y.; Letunovska, N.; Shevliuga, O. 2017. Competitive and sustainable technological development: focus on business enterprises, Journal of Security and Sustainability Issues 6(3): 491-500. http://dx.doi.org/10.9770/jssi.2017.6.3(13) 
The International Journal

ISSN 2345-0282 (online) http://jssidoi.org/jesi/

2017 Volume 4 Number 4 (June)

http://doi.org/10.9770/jesi.2017.4.4(3)

Tetsman I.; Vekteris, V.; Mokšin V. 2017. Investigation of the efficiency of the lateral exhaust hood enhanced by aeroacoustic air flow, Process safety and environmental protection. Rugby: Institution of Chemical Engineers 109 (2017): 224-232.

Tvaronavičienè, M.; Černevičiūtè, J. 2015. Technology transfer phenomenon and its impact on sustainable development, Journal of Security and Sustainability Issues 5(1): 87-97. http://dx.doi.org/10.9770/jssi.2015.5.1(7)

Uruburu, A.; Ponce-Cueto, E.; Cobo-Benita, J. R.; Ordieres-Meré, J. 2013. The new challenges of end-of-life tyres management systems: A Spanish case study.Waste Management. 33(3): 679-688

Wu, B.; Zhou, M.H. 2009. Recycling of waste tyre rubber into oil absorbent. Waste Management. 29(1): 355-359

Ina TETSMAN is an Assoc. Professor, Department of Mechanical Engineering, Vice Dean Faculty of Mechanics, Vilnius Gediminas Technical University. Doctor of Technological Sciences (Mechanical Engineering): Assoc. Professor (2009 till now Vilnius Gediminas Technical University). Publications: author of 2 study-guides, over 20 research papers and 1 invention. Research interests: environment and soil protection methods and equipment, waste management, wastewater pollution.

ORCHID ID: 0000-0002-1096-5389

Kristina BAZIENE is a lector, Department of Mechanical Engineering, Vilnius Gediminas Technical University (since 2015). Doctor of Science (Environmental engineering), VGTU, 2013. Publications: author of more then 20 research papers. Research interests: municipal waste management, landfill, waste recycling. K. Baziene have got two traineeships and temporary studies abroad (Southampton University, United Kingdom and Queen's University, Canada).

ORCHID ID: 0000-0002-1758-8424

Gintas VISELGA is Dr., Assoc. Professor, Department of Mechanical Engineering, Vice Dean Faculty of Mechanics, Vilnius Gediminas Technical University (VGTU). Doctor of Technological Sciences (mechanical engineering), Litchuanian Institute of Agricultural Engineeering, 1998. Employment: Assoc. Professor (2004-2015 Vilnius Gediminas Technical University, 2010-2015 Lithuanian University of Educational Sciences), Lecturer (2000-2010 Vilnius Pedagogical University, 2003-2004 Lithuanian University of Agriculture), senior assistant (1999-2000 Vilnius Pedagogical University), senior researcher (1999-2004 Lithuanian Institute of Agricultural Engineering), researcher (1998-1999 Lithuanian Institute of Agricul-tural Engineering). Publications: author of 8 study-guides, over 60 research papers and 2 inventions. Research interests: environment and soil protection methods and equipment, gantry systems and their power modules, soil cultivation, potato growing methods and equipment.

ORCHID ID: 0000-0001-5621-0427

Register for an ORCID ID:

https://orcid.org/register

Copyright (C) 2017 by author(s) and VsI Entrepreneurship and Sustainability Center

This work is licensed under the Creative Commons Attribution International License (CC BY).

http://creativecommons.org/licenses/by/4.0/

(c) (i) Open Access 